\title{
Valdivia Á., J. G. (2016). Mariano Melgar 200 años: crítica, nación e independencia. Arequipa, Perú: Centro de Investigación y Desarrollo Cultural del Sur del Perú, Revista de Crítica Literaria Latinoamericana y Latinoamericana Editores.
}

Siempre será incalculable el valor de una obra que aporte a la investigación literaria sobre la identidad, la ideología y la manifestación cultural sudamericana. Esto a través del estudio de personajes que hayan contribuido a la formación de la identidad nacional de un país tan diverso como el nuestro. Por ello, creemos necesario hacer referencia a la labor investigadora de José Gabriel Valdivia, poeta, periodista y docente universitario peruano, quien ha dedicado gran parte de su labor académica a profundizar y orientar los estudios acerca de la lírica arequipeña.

Debido a la dispersión de los pocos y heterogéneos trabajos que existen sobre la lírica arequipeña, especialmente sobre Mariano Melgar, es elogiable la labor de Valdivia, quien ha logrado rescatar en esencia 36 materiales de investigación. Entre ellos se incluye una entrevista en la que se habla de la revalorización del arte y la justificación de la formación literaria del autor del libro Mariano Melgar 200 años: crítica, nación e independencia.

Este libro de compilación de crítica literaria sobre Mariano Melgar se centra en la información biográfica e historicista vertida sobre el referido poeta durante el periodo comprendido entre los siglos XIX y XX. Al mismo tiempo, su autor pone énfasis en que, a partir del aporte de las fuentes, es necesario concluir que la obra de Melgar marca, sin duda alguna, el primer momento de la literatura peruana e incorpora oficialmente el elemento indígena, lo cual abre paso a la búsqueda de la identidad literaria peruana propiamente dicha.

El trabajo de selección se inicia con la crítica simplista y elitista de 1905 que realiza José de la Riva-Aguiero sobre las composiciones líricas del poeta Mariano Melgar, que entre adjetivos como "pobre poeta", "momento curioso", entre otros, reduce su contribución únicamente a la iniciativa de introducir el 
tema y el tono de la tristeza del indio en la lírica del siglo XIX. Obviamente, la suya resulta una mirada elitista de la creación del joven poeta y mártir.

Luego, Valdivia nos inserta en un camino cada vez más apasionante en el que el lector irá descubriendo paso a paso la valoración literaria que cobra Melgar con el paso del tiempo, a través de las investigaciones cada vez más profundas que generan las distintas corrientes de interpretación literaria en el Perú. Y así nos topamos con el, un tanto idealizado, discurso de los críticos conservadores y elitistas que consideraban la poética melgariana como ensayos de una melancolía autóctona, en las que se insertan melodías españolas con acordes de guitarra que reemplazan al sonido de las quenas de los aravis o harauis del Ande, obra que intenta fundar un género nacional. Pero es el escritor y sociólogo peruano José Carlos Mariátegui, autor de Siete ensayos de interpretación de la realidad peruana, resalta la imagen del joven poeta arequipeño. Valdivia ubica las referencias específicas sobre Melgar, ya que constituyen un aporte que realizara el ensayista, y las incluye acertadamente en esta selección de trabajos. En los tratados seleccionados de Mariátegui, se reconoce a Melgar como el precursor del romanticismo literario en Sudamérica. Asimismo, para él se mezclan dos imágenes en el joven poeta: la del prócer y el poeta. Se reconoce con esto la ruptura con el análisis elitista que había planteado inicialmente José de la Riva-Agüero, quien ubicó al poeta como autor neoclásico, romántico y creador del yaraví, desmerecedor de cualquier aporte a nuestra lírica.

Comenzamos a notar que la recopilación de escritos que abordan el tema melgariano está organizada cronológicamente con la finalidad de demostrar que a través del tiempo los muchos críticos le fueron dando mayor espacio y relevancia al poeta arequipeño. Por otro lado, el carácter analítico de los diversos y reconocidos investigadores como Aurelio Miró Quesada, Raúl Porras Barrenechea y José Rada y Gamio, entre otros, se centra en la exploración histórica y biográfica del poeta, lo que nos sitúa contextualmente para comprender la situación que envolvía al vate en torno de sus escritos, tales como su formación académica eclesiástica orientada por su progenitor, Juan de Dios 
Melgar, las primeras fuentes clásicas con las que tiene contacto y su interés por los principales poetas latinos como Ovidio.

En la introducción de este libro se hace referencia a la formación académica en retórica, matemáticas y física del joven poeta, lo cual evidencia su amplia erudición en muchas disciplinas, documentadas y registradas en archivos de los centros donde se educó y enseñó Mariano Melgar. Esto sin duda aleja todo juicio erróneo y desvalorizador que tenían algunos críticos de antaño sobre el vate arequipeño. Por otro lado, en el aspecto temático y creativo de Melgar contamos con las disertaciones de Antonio Cornejo Polar, Jorge Cornejo Polar, Estuardo Núñez, Francisco Mostajo, Luis Fabio Xammar, entre otros, los mismos que concuerdan que Melgar se adelantó al establecimiento del romanticismo en el Perú, lo que lo hace ganador del reconocimiento popular. Además declaran que el joven Melgar era pues adelantado para su época por la vida romántica que lo impulsa, bajo la influencia de la lírica italiana y española, de las que adopta el empleo de vocativos femeninos bucólicos en su lírica breve. Cabe señalar que en la selección que Valdivia muestra de Luis Xammar, este último, desgraciadamente, yerra al señalar que el obispo Chávez de la Rosa orientó la formación de Melgar, pues el mencionado clérigo se hallaba ya en Ayacucho cuando Melgar ingresó al seminario de San Jerónimo.

Finalmente consideramos que, sin desmerecer los demás artículos, también valiosos, es el trabajo de Antonio Cornejo Polar el que fortalece la imagen del poeta, quien durante mucho tiempo fue relegado a la clasificación de simplista por el hecho de recopilar la rima sencilla de la lírica andina, sin considerar que el estilo sentaba las bases de una producción literaria propiamente peruana. En “Los yaravíes de Mariano Melgar”, Cornejo Polar aclara perfectamente la diferencia entre los tipos de lírica popular y lírica tradicional para poder explicar locuazmente la inscripción melgariana en el imaginario del pueblo y en la literatura peruana.

Por lo que hemos podido apreciar en Mariano Melgar 200 años: crítica, nación e independencia, José Gabriel Valdivia no desdeña los estudios de algunos 
críticos por más simples o contrarios que estos puedan ser para estudiar la lírica de Melgar. Lo que hace su autor es ordenarlos cronológicamente para darle al lector una mirada panorámica sobre cómo, junto con la aceptación canónica del tema mestizo y la lírica andina, poco a poco se fue profundizando y revalorizando la búsqueda de la identidad lírica peruana con la poética de Melgar, más allá de prejuicios elitistas que, en su momento coetáneo, eran preponderantes.

La finalidad de la obra es pues facilitar diversas fuentes que sirvan al investigador para el planteamiento de nuevos rumbos en los estudios en torno de la poética de Melgar y su aporte a la literatura peruana. Asimismo, establece la diferencia de lo que en su contexto era lo popular para Melgar (mestizo), no lo indígena. Precisamente el deslinde entre la lírica popular y lírica tradicional se encuentra sustentado en el texto compilado de Antonio Cornejo Polar.

Liliana Ramírez Durand, Universidad Peruana Cayetano Heredia ines.ramirez@upch.pe

\section{Referencias bibliográficas}

Cornejo Polar, A. (1982). Sobre la literatura de la emancipación en el Perú. Sobre literatura y crítica latinoamericanas. Caracas, Venezuela: Universidad Central de Venezuela.

García Calderón, V. (1986 [1914]). Obras escogidas. Lima, Perú: Ediciones Edubanco, Fundación del Banco Continental para el Fomento de la Educación y la Cultura.

Mariátegui, J. C. (1915). Recordando al prócer, La Prensa, 12 de marzo, p. I. . (1928). Siete ensayos de interpretación de la realidad peruana. Lima,

Perú: Ed. Amauta.

Xammar. L. (1944). Mariano Melgar, Obra poética. Lima, Perú: Ediciones Durán. 